\title{
Ratios between aboveground net primary production, litterfall and carbon stocks in scots pine stands (Russia)
}

\author{
Andrey F. Osipov ${ }^{1}:{ }^{\mathrm{i}}$, Ivan N. Kutjavin ${ }^{1 \mathrm{iD}}$, Kapitolina S. Bobkova ${ }^{1}$
}

${ }^{1}$ Institute of Biology of Komi Science Centre of the Ural Branch of the Russian Academy of Sciences, Syktyvkar, Komi Republic, Russia

SILVICULTURE

\begin{abstract}
Background: Forests are the main terrestrial regulators of greenhouse gas concentrations. However, estimates of carbon fluxes in them are characterized by large uncertainties. Therefore, the derivation of predictors for their assessment is an urgent task. The aim was to assess the carbon stocks in the biomass to characterize the intensity of aboveground net production and the amount of litterfall in Scots pine forests of different types on the North-East of the Europe. We estimated biomass and aboveground net primary production (ANPP) of stands using sample trees. For vegetation of ground cover biomass and primary production evaluating, we cut off all aboveground organs on an area of $625 \mathrm{~cm}^{2}$ and removed the first-year parts. Litterfall was collected over 3-6 years using litter traps.
\end{abstract}

Results: Most of the carbon in the biomass of pine forests is concentrated in trees $\left(\mathrm{C}_{\text {stand }}\right)$ with dominating role of stem wood. However, in boggy forests, ground vegetation plays a significant role in carbon stocks, both in absolute and relative values. We estimated carbon fluxes in ANPP and stand litterfall. High contribution of needles was detected for these flows. The ratio between ANPP and $C_{\text {stand }}$ varied from 0.018 to 0.056 but between Litterfal and $C_{\text {stand }}$ ranged from 0.008 to 0.024 .

Conclusion: The biomass, ANPP and litterfall depended form forest type. Obtained ratios between them can be used for assessing carbon fluxes in large regions using remote data collection of forest biomass.

Keywords: Carbon stocks, biomass, aboveground net primary production, litterfall

\section{HIGHLIGHTS}

The carbon stocks, net production and litterfall were presented for Scots pine forests.

Pine forests on North-East of Europe were characterized by low productivity.

The needles and leaves dominated in the annual litterfall of Scots pine forests.

Approach of carbon fluxes estimating in forest ecosystem was suggested.

OSIPOV, A. F.; KUTJAVIN, I. N.; BOBKOVA, K. S. Ratios between aboveground net primary production, litterfall and carbon stocks in scots pine stands (Russia). CERNE, v. 27, e-102567, doi: 10.1590/01047760202127012567 


\section{INTRODUCTION}

The ongoing climate change, associated with an increase in the concentration of greenhouse gases in the atmosphere, has led to the adoption of a number of intergovernmental climate agreements, the most recent of which is the Paris Agreement under the United Nations Framework Convention on Climate Change. If it is ratified, the Russian Federation will declare a reduction in greenhouse gas emissions by 2030 to $70-75 \%$ of the 1990 level, primarily due to taking into account the absorption capacity of forests. Forest ecosystems of the Russian Federation, which comprise about $20 \%$ of the area of the world's forests, play a tremendous role in the carbon cycle of the biosphere (FAO, 2010). Because of this, studies of the forest carbon cycle in this territory, as well as the impact of climate change on them, do not lose relevance (Schapoff et al., 2016). At present time estimates of carbon stocks in the biomass of Russian forests are fairly close, while carbon storage in soils and its temporal dynamic and fluxes have high uncertainties which are mainly due to a scarcity of experimental data (Schepaschenko et al., 2013; Thurner et al., 2014).

Primary production is a key component of forest carbon cycle (Pan et al., 2011). For large regions in boreal zone these parameter was estimated based on forest inventories data or "semi-empirical" method for assessing NPP that combined the Richards-Chapman growth function and yield tables (Shvidenko et al., 2007). As a predictor in assessing the net primary production of large forest areas, one can use data on the biomass of stands or wood reserves in them, employing conversion factors between them (Keeling and Phillips, 2007).

The opposite process of net primary production is litterfall. According to a Ortiz et al. (2013), difficulties in forecasting soil carbon dynamics are due to uncertainties in predicting the mass of litterfall, which is a connecting link in the carbon cycle between soil and biomass (Smith et al., 2015). To forecast of the amount of litterfall entering the soil surface have been used data on the biomass (Ťupek et al., 2015) and net primary production (Lv et al., 2013; Park, 2015) of needles, radial growth of stem wood (Lehtonen et al., 2004), weather conditions (Portillo-Estrada et al., 2013; Bhatti and Jassal, 2014) with that were determined close correlation.

In addition there are two indirect ways of assessing this flux: by the loss of carbon during respiration of the soil and by it's tying up in net primary production (Matthews, 1997). In our opinion, the use of soil respiration data for calculations of litterfall has substantial uncertainties associated with the lack of unambiguous assessments of the share of autotrophic respiration in the total $\mathrm{CO}_{2}$ flux from the soil surface (Goncharova et al., 2019). In this line, (Neumann et al., 2018) concluded that the availability of biomass data can lead to more reliable results compared to climatic parameters when assessing litterfall inflow.

An analysis of the literature showed that the information on the interrelation of net primary production or litterfall with biomass of stands for boreal forests is clearly not sufficient. We think that base on these ratios is possible to derivation of conversion coefficients, by analogy with those used to assess forest biomass (Schepaschenko et al., 2018). It will allow calculating carbon fluxes with net primary production and litterfall in forest ecosystems using biomass data. Thus, they will be helpful to reduce uncertainties when assessing carbon fluxes in the boreal zone. Our study therefore has the following objectives: 1 . to assess the carbon stocks in the Scots pine forest biomass, aboveground net primary production (ANPP), and intensity of litterfall inflow in Scots pine forests in Komi Republic (Russia) 2. to calculate the ratio between ANPP and litterfall and carbon stocks in the aboveground organs of stands.

\section{MATERIAL AND METHODS}

\section{Study area}

The experiments were performed on the territory of Komi Republic (region of Russia) that locates on NorthEastern of East European Plain (Fig. 1). The objects under study were placed in the Chernam ( $\mathrm{N} 62^{\circ} 01^{\prime} \mathrm{E} 50^{\circ} 28^{\prime}$ ) and Lyal ( $\mathrm{N} 62^{\circ} 17^{\prime} \mathrm{E} 50^{\circ} 40^{\prime}$ ) forest ecological stations of the Institute of biology of the Komi Scientific Center of the Ural Branch of the Russian Academy of Sciences and in the

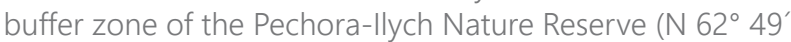
$\left.\mathrm{E} 56^{\circ} 52^{\prime}\right)$. The climate in the territory under consideration is temperate continental. Mean annual air temperature varies from +0.3 to $+0.5^{\circ} \mathrm{C}$ (Chernam and Lyal forest ecological stations); closer to the Ural Mountains, it decreases to $-0.8^{\circ} \mathrm{C}$, with a simultaneous increase in the amount of precipitation from 620 to $675 \mathrm{~mm}$, most of which falls during the warm period of the year. The mean duration of the growing season is 141 days, while the number of days with stable snow cover is 165-175 days.

\section{Data collection}

The work was carried out on permanent sample plots of a rectangular shape embedded in Scots pine forests of different growing conditions and ages. The plot size varied from 0.12 to 0.20 ha. Within each site, tree diameters at breast height with a thickness of more than 6 $\mathrm{cm}$ and total heights of all living trees were measured into account. A brief description of the stands is given in Tab.1. The growing stock was calculated according to regional tables, depending on the diameter and height of the tree. The forest types were determined according to classes of soil moisture conditions: stands on over-wetted soil (Sphagnosa type), stands on soils with sufficient moisture (Myrtillus type), and stands on dry soils (Lichen type).

The biological productivity of the stands was assessed using 5-16 sample trees selected at each site (Usoltsev, 2007; Repola, 2009). The trees must be healthy and without visible defoliation, change in the main growth axis, stem curvatures, decay signs, frost clefs, or caves. The sample trees were performed after the end of the active growth period and before leaf fall, usually in mid-August. The sample tree selection was based on diameter at breast height $(\mathrm{DBH})$ distribution of all trees in the stand. One or two sample trees were equal to the mean diameter of the 


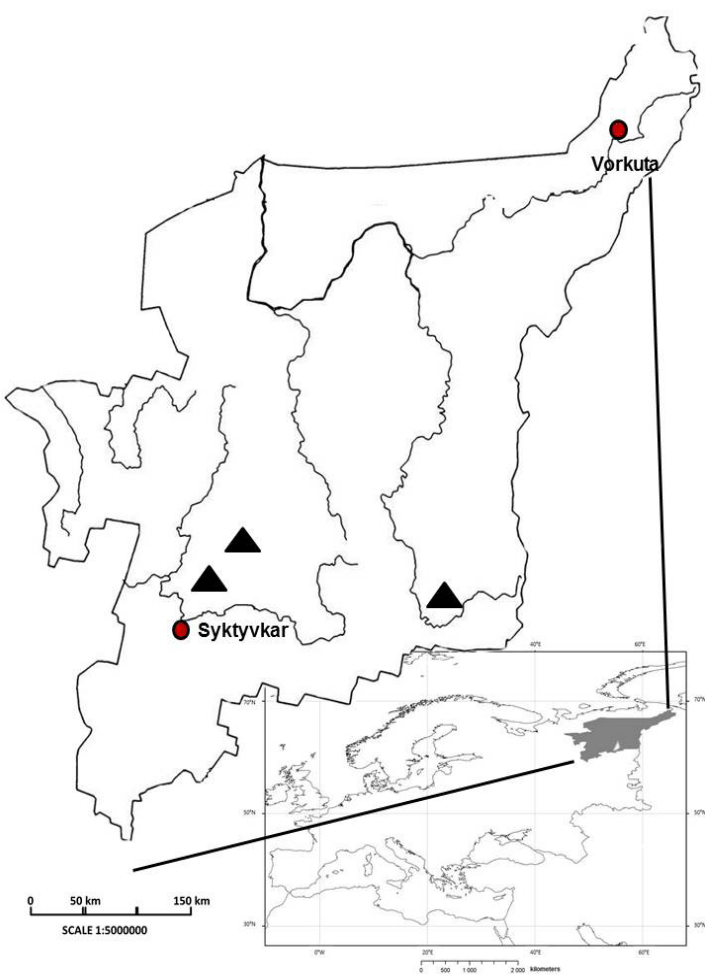

stand belongs. One sample tree was close to the largest on diameter trees and one to the smallest trees. The other trees were taken randomly from the range between largest and smallest $\mathrm{DBH}$.

The aboveground part of each sample tree was partitioned into next fractions: stem, branches and twigs with needles. For this purpose, the tree was cut into 2-m sections from root collar and weighed. After fresh mass weighting from each section were taken next samples: in first, sample discs were cut from stem for wood/bark ratio determining; in second, twigs with needles samples were collected for twig/needles ratio and their distribution on age. In addition to all samples were used for water content determining in biomass fractions. The roots were excavated from soil and weighed. After that the samples for water content determination were collected. Further processing
Fig. 1 Location of study sites (triangle points) on Komi Republic and on Europe map (in down right corner). was carried out in a laboratory. Samples were packed in plastic bags to water content preserve.

To determine the biomass of the ground cover vegetation all aboveground organs were cut off on 40-50 plots with an area of $0.25 \mathrm{~m} \times 0.25 \mathrm{~m}$ on distance $4-5 \mathrm{~m}$ between from each other. Samples of plants for analysis of biomass were collected in mid-August. Sampling in late summer aimed at estimating the maximum biomass accumulation of all species during the growing season (Woziwoda et al., 2014). Underground organs were collected using a drill with an area of $98 \mathrm{~cm}^{2}$ in 40-50 cores to a depth of $20 \mathrm{~cm}$. To determine the production of shrubs in Myrtillus and Lichen type pine forests, we randomly cut off 10-50 samples of shrubs on PL1 and PM². The number of samples depended on the species frequency occurrence.

Tab. 1 Characteristic of Scots pine stands.

\begin{tabular}{|c|c|c|c|c|c|c|c|}
\hline Stand code & Stand composition & $\begin{array}{c}\text { Mean age } \\
\text { (years) }\end{array}$ & $\begin{array}{c}\text { Density } \\
\left(\text { trees.ha }^{-1}\right)\end{array}$ & $\begin{array}{c}\text { Basal area } \\
\left(\mathrm{m}^{2} . \mathrm{ha}^{-1}\right)\end{array}$ & $\begin{array}{c}\text { Growing stock } \\
\left(\mathrm{m}^{3} \text {.ha- }{ }^{1}\right)\end{array}$ & $\begin{array}{c}\text { Mean height } \\
(\mathrm{m})\end{array}$ & $\begin{array}{c}\text { Mean diameter } \\
(\mathrm{cm})\end{array}$ \\
\hline \multicolumn{8}{|c|}{ Pine forests Lichen type } \\
\hline$P L 1$ & $10 \mathrm{P} \mathrm{s.} \mathrm{B}^{1}$ & $84 \pm 5^{2}$ & 2533 & $32.0 \pm 1.8$ & $246 \pm 17$ & $13.9 \pm 0.2$ & $11.6 \pm 0.3$ \\
\hline PL2 & $10 \mathrm{P}$ & $180 \pm 20$ & 908 & $21.6 \pm 2.0$ & $177 \pm 19$ & $14 \pm 0.4$ & $14.3 \pm 0.3$ \\
\hline \multicolumn{8}{|c|}{ Pine forests Myrtillus type } \\
\hline$P M 1$ & 9P1B s. S & $60 \pm 4$ & 1730 & $24.9 \pm 1.3$ & $205 \pm 13$ & $14.4 \pm 0.2$ & $15.9 \pm 0.3$ \\
\hline PM2 & $9 \mathrm{P} 1 \mathrm{~B}+\mathrm{S}$ & $94 \pm 7$ & 1195 & $27.8 \pm 1.3$ & $220 \pm 12$ & $15.0 \pm 0.3$ & $19.1 \pm 1.3$ \\
\hline \multicolumn{8}{|c|}{ Pine forests Sphagnosa type } \\
\hline PS1 & $9 \mathrm{P} 1 \mathrm{~B}+\mathrm{S}$ & $42 \pm 2$ & 2153 & $15.0 \pm 0.6$ & $95 \pm 5$ & $8.8 \pm 0.1$ & $9.3 \pm 0.2$ \\
\hline PS2 & $10 P+B$ s.S & $60 \pm 4$ & 2040 & $15.7 \pm 0.6$ & $109 \pm 5$ & $10.0 \pm 0.1$ & $10.0 \pm 0.2$ \\
\hline PS3 & $10 P+B, S, A$ & $118 \pm 4$ & 1210 & $20.2 \pm 1.0$ & $169 \pm 10$ & $12.9 \pm 0.2$ & $16.3 \pm 0.4$ \\
\hline
\end{tabular}

${ }^{1}$ Stand composition was calculated according to input of species in total growing stock. One unit is equal to $10 \%$ from total growing stock. Species: $P-$ Pinus sylvestris, B - Betula pubescens, S - Picea obovata, A - Populus tremula; s - single (input $<1 \%$ ); " + " - input from 1 to $4 \% .{ }^{2}$ Mean \pm standard error 
The inflow of tree litterfall to the soil surface was assessed using 15-20 litter traps of $0.25 \mathrm{~m}^{2}$ that were installed on distance about $5 \mathrm{~m}$ from each other on sites within 3 or more years (Portillo-Estrada et al., 2013). Litterfall was collected twice a year: after snow melting in mid-May and after leaf fall in mid-October. The observation period was different for the stands and given in Tab. 4 .

\section{Cameral processing of data}

Under laboratory conditions stem samples of trees were separated into bark and wood. The twigs with needles samples were divided on components with age of fractions determining. Then their fresh mass was weighted. The samples of ground vegetation were sorted into individual plant species. The shoots of first year were cut from sample shrubs for their increment evaluating. The following fractions were separated into the litterfall samples: needles, leaves, branches, bark, and cones. If the litterfall fragments were difficult to differentiate due to their small size, they were placed into a separate fraction, plant remains (Portillo-Estrada et al., 2013), which mainly included bud scales, small fragments of needles, or bark. All samples after cameral processing were dried to absolute dry weight at a temperature of $105^{\circ} \mathrm{C}$ and weighted. After drying the water content was determined in samples of sample trees for each fraction.

\section{Data analysis}

The mass of the tree roots in Lichen and Sphagnosa types Scots pine forests was calculated by the equation using the ratio of the aboveground and total tree mass (Mokany et al., 2006). Needle growth was assessed as mean by the contribution of the needle mass over 4 years to the total mass. The current growth of stem wood was determined as the mean over the past 5 years by the cuts of stem wood that were made at the level of the root neck, the heights of 1 and $1.3 \mathrm{~m}$, and then every 2 meters up to the top. For this purpose analysis of the radial growth of the stem wood was carried out by four radii using the tree-ring measurement station LINTAB and TM 5 (RINNTECH ${ }^{\circledR}$, Germany) and software for treering measurement and analysis TSAP-WinTM (RINNTECH ${ }^{\circledR}$, Germany). According to these data, a tree growth progress by height and diameter was built. The bark increment was taken equal to its litterfall. Branch growth was determined by the middle branch selected from the middle of the crown of each tree as the sum of the middle branch's mean growth of the first order and all branches of the second order, using the following equation [1], where I is the growth of the middle branch (mass units), Mbrl is the mass of the first-order branch (mass units), Mbrll is the mass of the second-order branch (mass units), $\mathrm{A}$ is the age of the branch (years).

Based on sample trees data, we derived equations for the dependence of mass and increment of separate fractions from the diameter at breast height of the form $M=a \times D^{b}$, where $M$ is dry mass of biomass or increment component $(\mathrm{kg}), \mathrm{D}$ is $\mathrm{DBH}(\mathrm{cm})$, and $\mathrm{a}$ and $\mathrm{b}$ are constants (Tab. 2). Type of equation was chosen based on the analysis of the approximating curve. The curve should not cross the
$I=\frac{M_{\text {brl }}}{A}+\sum_{n=1}^{n} \frac{M_{\text {brll }}}{A}$

abscissa axis, which leads to negative values of biomass and increment. This type of equation provided accurate biomass predictions (Payne et al., 2019). For sample shrubs we calculated share of the first year shoots from total mass. The data are presented in Tab. 3. The growth of herbaceous plants was taken equal to their biomass. The ratio between the growth and the total mass of shrubs in pine forests of Sphagnosa type and mosses in all studied sites was calculated according to published data. For Vaccinium myrtillus and $V$. uliginósum this indicator was taken equal to 17\%, for $\mathrm{V}$. vitis-

Tab. 2 Equations $\left(y=a \times D^{b}\right)$ for the dependence of the biomass (above line) and net primary production (under line) of Pinus sylvestris trees fractions on the diameter at breast height $(D), k g($ at $p<0.05)$.

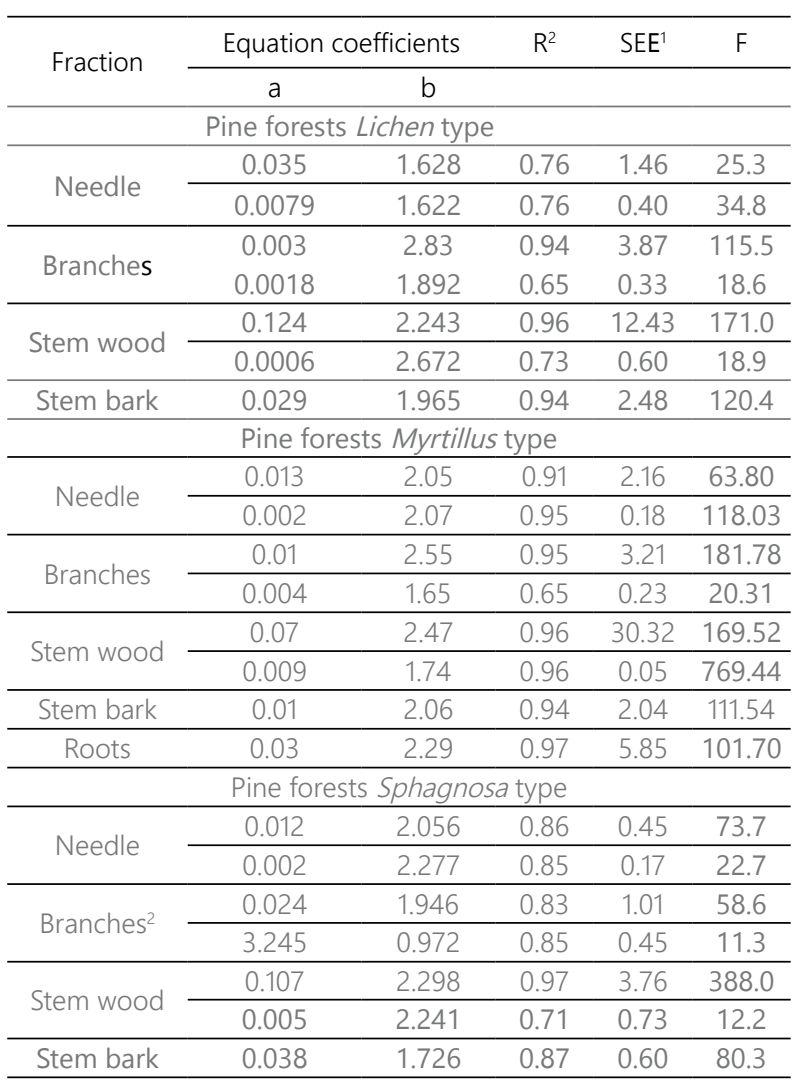

${ }^{1} \mathrm{SEE}$ - standard error of equation. ${ }^{2}$ For Scots pine trees branches increment was used equation by form $y=a \times\left(D^{2} \times H\right)^{b}$.

Tab. 3 Annual increment of shrubs in pine forests, \% of first years organs from aboveground mass (mean $\pm \mathrm{SE}$ ).

\begin{tabular}{cccc}
\hline Species & Lichen type & $\begin{array}{c}\text { Myrtillus } \\
\text { type }\end{array}$ & p-value \\
\hline Vaccínium myrtillus $L$ & $40 \pm 16(27)^{1}$ & $37 \pm 3(25)$ & 0.453 \\
Vaccínium vítis-idaea $L$ & $44 \pm 5(50)$ & $30 \pm 3(20)$ & 0.002 \\
Vaccinium uliginosum $L$. & - & $25 \pm 3(10)$ & \\
Empetrum nigrum $L$ & - & $19 \pm 2(10)$ & \\
\hline
\end{tabular}

1 in brackets - number of samples. ${ }^{2}$ Differences between sites were checked by ANOVA test 
idaea - 16\%, for Ledum palustre - 10\% (Kazimirov et al., 1977), Sphagnum mosses - 32\% (Laiho et al., 2011), green mosses 22\% (Goncharova and Sobachkin, 2014).

Carbon content of biomass and litterfall was taken as 50\% of separate components mass (Payne et al., 2019). The aboveground net primary production was calculated as sum of increment all aboveground tree organs (needle/ leaves, stem wood, stem bark, branches) and vegetation of ground cover (shrubs, mosses, grass and lichens). The ratios between aboveground net production, litterfall inflow, and carbon stocks in the stand biomass were calculated using the following equation [2], where $\mathrm{R}$ is the ratio between the ANPP or Litterfall and $C_{\text {stand }}$ A is ANPP or Litterfall; $C$ is carbon stocks in the stand biomass.

$$
R=\frac{A}{C^{\prime}}
$$

Basic descriptive statistics (mean, maximum, and minimum) were used to describe the experimental data. The standard error of the estimate (SEE) was calculated for biomass and increment equations. It is represents the main distance that the observed values deviate from the regression line. Normal distribution was tested using the ShapiroWilk test. The homogeneity of variances was checked by Bartlett test. In case normal distribution one-way ANOVA was applied for sites differences testing. The Tukey HSD test was used for multiple pairwise comparison of group. In case the non-normal distributed nature of data set a Kruskal-Wallis one-way analysis of variance was used to test the significance of differences between sites and Dunn test for post-hoc test following Kruskal-Wallis test. Statistical analysis was performed at $95 \%$ significant level. Statistical processing of data was performed using the programs Microsoft Excel 2010 and R statistical programming package version 3.5.0 (R Core Team, 2018).

\section{RESULTS}

\section{Carbon stocks in the biomass of pine forests}

The results given in Fig. 2 show a wide variation in carbon stocks of the biomass $\left(C_{\text {biomass }}\right)$ in Scots pine forests.

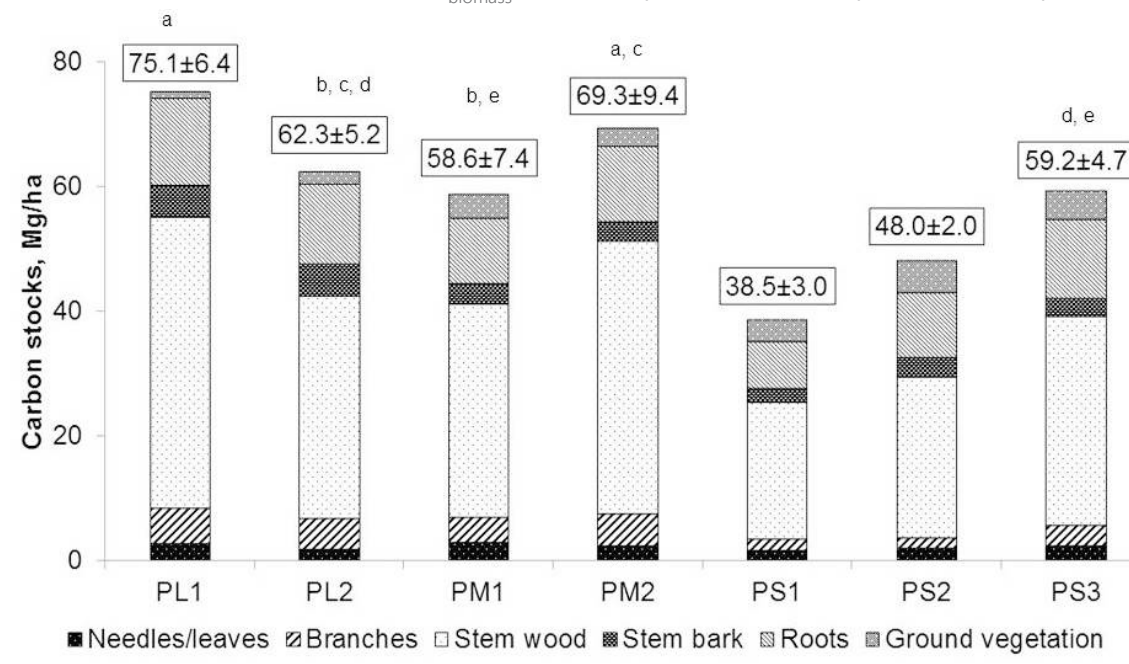

A higher mass was noted in the PL1 stand and a lower mass in the Shagnosa type. The ANOVA showed that there are significant differences in $C_{\text {biomass }}$ between the studied sites $(F=34.76, p=0.000)$. The pairwise comparison ( 21 couples) of total biomass showed that there are no disparities between carbon stocks in PM1 and PL2 $(p=0.869), P M 1$ and PS3 $(p=0.999), P M 2$ and PL1 ( $p=0.463), P M 2$ and PL2 ( $p=0.252)$.

Living trees are the main pool of $C_{\text {biomass' }}$ with a proportion of $89-99 \%$. The main fraction comprising more than half (53-62\%) of $C_{\text {biomass }}$ is the wood of tree stems, whereas needles/leaves account for 3-5\%, branches for $3-8 \%$, stem bark for $4-8 \%$, and roots for $18-22 \%$. According to Kruskal-Wallis test there were no significant differences in the proportion of needles and branches in $C_{\text {biomass }}$ between the sites ( $p=0.264$ and $p=0.181$, respectively). However, share of stem wood, stem bark, roots and ground vegetation were depended from site $(p<0.05)$.

\section{Aboveground net carbon production}

The growth of aboveground organ biomass (ANPP) in Scots pine forests varied from 1.29 to $2.91 \mathrm{Mg} \cdot \mathrm{C} \cdot \mathrm{ha}^{-1}$ per year (Fig. 3). The Kruskal-Wallis test showed that total ANPP differed between studied sites $(p=0.000)$. Carbon tied up in ANPP comprised 2-6\% of its stocks in the aboveground organs. A more intense accumulation of ANPP was noted in middle-age PM1, while a less intense one was found for young PS1. The contribution of individual fractions of the biomass to ANPP varied widely and differed between Scots pine stands $(p=0.000)$. For instance, the share of needles varied from 21 to $32 \%$, that of stem wood from 26 to $53 \%$, that of stem bark from 2 to $9 \%$, that of branches from 10 to $27 \%$, and that of ground vegetation from 7 to $29 \%$.

\section{Carbon inflow with tree litterfall}

A relatively high intensity of carbon inflow onto the soil surface was observed in PL1 and PM2 stands (Tab. 4 ), and a lower intensity was observed in the over-mature PL2. The Kruskal-Wallis test showed significant differences in total aboveground litterfall mass between studied Scots pine forests $(p=0.001)$. However Dunn test detected that
Fig. 2 Carbon stocks in pine forests biomass. In frame above diagram is total carbon stock in a pine forest biomass (mean \pm standard error). Carbon stocks in columns sharing the same letter were not significantly different from each other. 


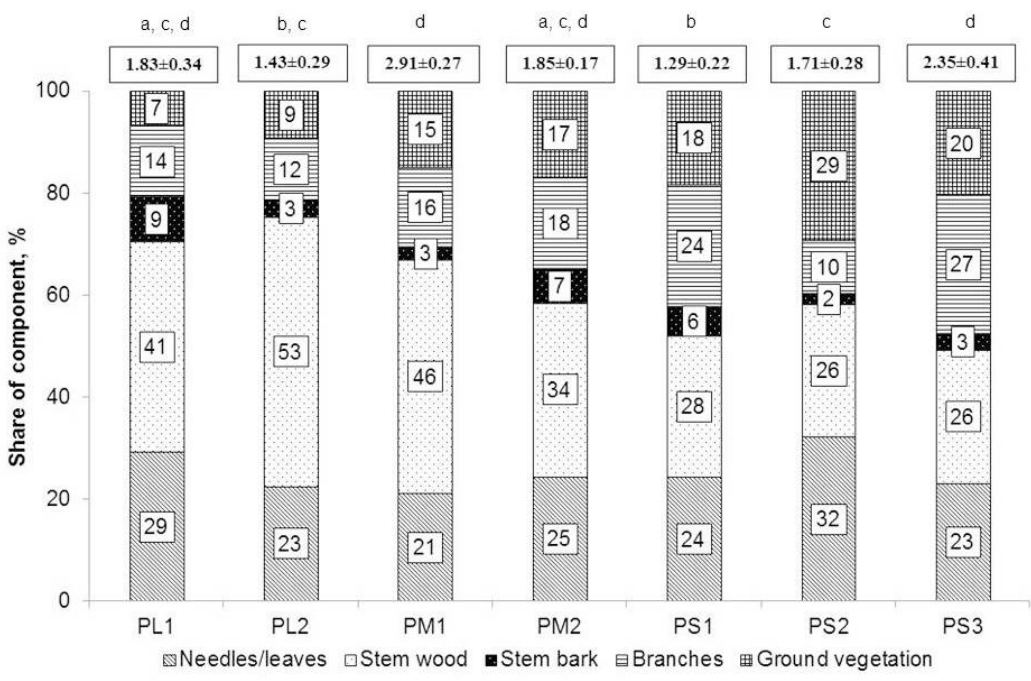

Fig. 3 Aboveground net primary production of pine stands. In frame on diagram is share of component. In frame above diagram is aboveground net primary production (mean \pm standard error). ANPP in columns sharing the same letter were not significantly different from each other.

Tab. 4 Litterfall production in Scots pine forests, $\mathrm{kg} \mathrm{C/ha} \mathrm{per} \mathrm{year.}$

\begin{tabular}{|c|c|c|c|c|c|c|c|c|c|c|c|c|c|c|}
\hline \multirow{2}{*}{ Fraction } & \multicolumn{2}{|c|}{ PL1 (2014-2018) ${ }^{1}$} & \multicolumn{2}{|c|}{ PL2 (2011-2013) } & \multicolumn{2}{|c|}{ PM1 (1977-1982) } & \multicolumn{2}{|c|}{ PM2 (2011-2018) } & \multicolumn{2}{|c|}{ PS1 (2007-2010) } & \multicolumn{2}{|c|}{ PS2 (1982-1985) } & \multicolumn{2}{|c|}{ PS3 (2008-2010) } \\
\hline & Mean \pm SE & $\begin{array}{c}\text { Min-Max } \\
(C V, \%)\end{array}$ & Mean \pm SE & $\begin{array}{l}\text { Min-Max } \\
(C V, \%)\end{array}$ & Mean \pm SE & $\begin{array}{l}\text { Min-Max } \\
(\mathrm{CV}, \%)\end{array}$ & Mean \pm SE & $\begin{array}{c}\text { Min-Max } \\
(\mathrm{CV}, \%)\end{array}$ & Mean \pm SE & $\begin{array}{c}\text { Min-Max } \\
(\mathrm{CV}, \%)\end{array}$ & Mean \pm SE & $\begin{array}{l}\text { Min-Max } \\
(\mathrm{CV}, \%)\end{array}$ & Mean \pm SE & $\begin{array}{c}\text { Min-Max } \\
(\mathrm{CV}, \%)\end{array}$ \\
\hline Pine needle & $684 \pm 16^{2}$ & $644-715$ (5) & $250 \pm 15$ & $232-279(10)$ & $356 \pm 33$ & $\begin{array}{c}271-490 \\
(23)\end{array}$ & $496 \pm 29$ & $393-603(16)$ & $461 \pm 55$ & $\begin{array}{c}353-531 \\
(21)\end{array}$ & $237 \pm 26$ & $\begin{array}{c}182-279 \\
(20)\end{array}$ & $351 \pm 36$ & $\begin{array}{c}269-421 \\
(18)\end{array}$ \\
\hline $\begin{array}{l}\text { Spruce needle5 } \\
\text { pANOVA }=0.000\end{array}$ & n. $0^{3}$ & n. $0^{3}$ & n.o & n.o & $2 \pm 1$ & $1-5(55)$ & $25 \pm 3$ & $15-40$ (33) & $3 \pm 1$ & $2-4(32)$ & $1 \pm 1$ & $0-4(110)$ & $11 \pm 2$ & 8-15 (24) \\
\hline $\begin{array}{c}\text { Birch leaves } \\
\text { pANOVA }=0.000\end{array}$ & $39 \pm 2$ & $35-45(12)$ & n.o & n.o & $102 \pm 4$ & $93-112(8)$ & $97 \pm 6$ & 77-134 (14) & $16 \pm 2$ & $14-19(16)$ & $226 \pm 22$ & $\begin{array}{c}192-263 \\
(25)\end{array}$ & $29 \pm 2$ & 24-33 (13) \\
\hline Aspen leaves5 & n.o & n. o $^{3}$ & n.o & n.o & n.o & n.o & n.o & n.o & n.o & n.o & n.o & n.o & $6 \pm 2$ & $2-10(50)$ \\
\hline $\begin{array}{l}\text { Branches (total) } \\
p(K W T)=0.005\end{array}$ & $183 \pm 11$ & $161-204(12)$ & $25 \pm 9$ & $7-43(64)$ & $86 \pm 13$ & $57-125(45)$ & $142 \pm 39$ & $61-310(62)$ & $67 \pm 24$ & $\begin{array}{c}36-114 \\
(62)\end{array}$ & $151 \pm 40$ & $88-242(55)$ & $41 \pm 7$ & $26-57(31)$ \\
\hline $\begin{array}{c}\text { Pine bark } \\
p(K W T)=0.002\end{array}$ & $146 \pm 23$ & 93-194 (31) & $47 \pm 5$ & $36-62(20)$ & $57 \pm 6$ & $39-75(25)$ & $123 \pm 8$ & 88-169 (16) & $63 \pm 7$ & $51-74(18)$ & $29 \pm 2$ & 25-33 (15) & $63 \pm 4$ & $57-71(10)$ \\
\hline $\begin{array}{c}\text { Pine ones } \\
p(K W T)=0.502\end{array}$ & $54 \pm 4$ & $45-65(15)$ & $35 \pm 19$ & $11-87$ (95) & $43 \pm 12$ & $11-74(67)$ & $85 \pm 22$ & $10-180(58)$ & $33 \pm 20$ & $5-71(105)$ & $41 \pm 20$ & 8-83 (80) & $49 \pm 18$ & $15-92(65)$ \\
\hline Rest5 & $57 \pm 7$ & 38-71 (29) & $29 \pm 7$ & $18-45(43)$ & $34 \pm 3$ & $25-48(10)$ & $56 \pm 6$ & $35-83(25)$ & $27 \pm 7$ & $14-39(46)$ & $29 \pm 5$ & $18-38(33)$ & $21 \pm 2$ & $16-25$ (18) \\
\hline $\begin{array}{c}\text { Total4 } \\
p(K W T)=0.001\end{array}$ & $1163 \pm 31$ & $1127-1203$ (3) & $386 \pm 27$ & $304-516(12)$ & $680 \pm 38$ & $\begin{array}{c}523-744 \\
(15)\end{array}$ & $1024 \pm 55$ & $\begin{array}{c}\text { 700-1357 } \\
(20)\end{array}$ & $670 \pm 64$ & $\begin{array}{c}549-783 \\
(18)\end{array}$ & $714 \pm 57$ & $\begin{array}{c}\text { 619-805 } \\
\text { (13) }\end{array}$ & $571 \pm 42$ & $\begin{array}{c}526-621 \\
(7)\end{array}$ \\
\hline
\end{tabular}

${ }^{1}$ In brackets is a period observation; ${ }^{2}$ inter-annual mean \pm standard error; ${ }^{3}$ n.o - not observed; ${ }^{4}$ Differences of total aboveground litterfall mass, bark, branches and cones between sites were checked by Kruskal-Wallis test (KWT) due to data non-normal distribution. Differences of photosynthetic organs litterfall (pine and spruce needles, birch leaves) between studied pine forests were tested by ANOVA; ${ }^{5}$ Testing of differences didn't performed or performed only for stands where was detected fraction.

there are no discrepancies in couples PM2-PL1 $(p=0.260)$, PS1-PM2 $(p=0.420)$, PS1-PM2 $(p=0.077)$, PS3-PL2 $(p=0.127)$, PS3-PM1 ( $p=0.334)$, PS3-PS1 $(p=0.292)$.

More than half of the tree litterfall was formed by pine needles, with the exception of pine forests PM2 and PS2. In general, the share of photosynthetic organs represented by pine and spruce needles and birch and aspen leaves varied from 60 to $72 \%$ and their mass depend on forest type (ANOVA: $F=17.4 ; p=0.000$ ). The Tukey HSD test showed that there are no differences in mass between stands within the Sphagnosa type $(p>0.05)$ and between them and PM1 ( $p>0.05)$. Also disparities were no in pairs PM2-PL1, PS3-PL2 and PS1-PM2 (total nine pairs from 21). The contribution of the bark in the pine forests varied within 4-13\% (here and elsewhere in this paragraph in brackets results of fraction's mass differences between sites using Kruskal-Wallis test: $p=0.002$ ), that of branches from $6-21 \%$ (Kruskal-Wallis test: $p=0.005$ ), and that of cones from $5-10 \%$ (Kruskal-Wallis test: $p=0.502$ ). We didn't observed significant differences both litterfall branches and bark in between stands PM2-PL1, PS1-PL2, PS1-PM1, PS3-PL2, PS3-PS1. Also there were no disparities between PS2-PL1, PS2-PM2, PL1-PL2 and PS3-PM1 in branches litterfall and between stands PM2-PM1, PM2-PL1 and PS1-PM2 in bark litterfall. In the studied pine forests, the mass of tree litterfall was 1.1-2.3 times less than that of ANPP and comprised 1.0-2.3\% of the carbon stocks in the aboveground organs of the stands. 


\section{Ratios between carbon stocks of the biomass, ANPP and litterfall}

Data of Tab. 5 show that the ANPP/Cstand ratio varied from 0.018 to 0.056 with a relatively high ratio in PM1, while a low ratio was found for PL2. The smallest variation between studied stands of this value was observed for pine forests of Sphagnosa type and largest was for Myrtillus type. The Tukey HSD test detected that there are no differences of investigated ratio between Scots pine stands within the types Lichen $(p=0.998)$ and Sphagnosa $(p>0.05)$. However according to ANOVA studied pine forests contrasted between each other $(p=0.000)$.

The ratio between litterfall and $\square$ stand varied widely from 0.008 to 0.024 with comparatively high level in Scots pine forests of Sphagnosa type $(p=0.000)$. The little values was detected in mature and overmature PS3 and PL2. In general, carbon tying-up in ANPP was 1.12-3.65 times higher than its inflow with litterfall. The highest values were noted in PM1 with more intensive ANPP and PL2 and PS3 where were low fluxes with litterfall $(p=0.000)$.

Tab. 5 Ratio between ANPP, litterfall production and aboveground stand biomass in Scots pine forests.

\begin{tabular}{lllllllll}
\hline \multirow{2}{*}{ Ratio } & p-value & \multicolumn{7}{c}{ Stand } \\
\cline { 2 - 8 } & PL1 & PL2 & PM1 & PM2 & PS1 & PS2 & PS3 \\
\hline $\begin{array}{c}\text { ANPP/ } \\
\text { Cstand }\end{array}$ & $<0.000$ & 0.022 & 0.018 & 0.056 & 0.028 & 0.038 & 0.038 & 0.039 \\
$\begin{array}{c}\text { Litterfall/ } \\
\text { Cstand }\end{array}$ & $<0.000$ & 0.019 & 0.008 & 0.015 & 0.019 & 0.024 & 0.022 & 0.014 \\
\hline $\begin{array}{c}\text { ANPP/ } \\
\text { Litterfall }\end{array}$ & $<0.000$ & 1.12 & 2.25 & 3.65 & 1.50 & 1.56 & 1.70 & 2.88 \\
\hline
\end{tabular}

${ }_{1}^{1}$ The differences of ANPP/Cstand and Litterfall/Cstand between sites were tested using ANOVA. The ANPP/Litterfall ratio was checked by Kruskal-Wallis test due to non-normal distribution of initial data.

\section{DISCUSSION}

\section{Carbon stocks and ANPP}

The comparison of obtained data with literature showed that our results on carbon storage are near to 85-year-old Myrtillus type Scots pine stand in Karelia (North-West of Russia) where biomass reach to $72.1 \mathrm{Mg} \cdot \mathrm{C}$ ha $^{-1}$ and variation is $72.1-159.6 \mathrm{Mg} \cdot \mathrm{C} \cdot \mathrm{ha}^{-1}$ (Sin'kevich et al., 2009) with ground vegetation share 1.8-6.2 \%. The biomass of a 50-year-old Scots pine forest is $86 \mathrm{Mg} \mathrm{C}$ ha $^{-1}$ in Southwestern Sweden and in 1.4 times higher than studied stand PM1 that akin to it's of type and age. (Hanson et al., 2013). The carbon mass in a 75-year-old Vaccinium type pine forest in Southern Finland comprises $78 \mathrm{Mg} \cdot \mathrm{ha}^{-1}$ (Kolari et al., 2004), which is close to that of the PL1 stand of a similar age, characterized by a fairly high density. The authors provide data showing that the vegetation of ground cover accounts for $1.5-4 \%$ of the total biomass. The variation of carbon in the biomass of Jack pine forests in Canada is 29-59 $\mathrm{Mg} \mathrm{ha}^{-1}$ (Bhatti and Jassal, 2014) that in 1.5 times lower than our studied pine stands of similar age and forest type. As noted by A. Park (2015) carbon stocks in Jack pine stands ranged from 38.8 to $59.6 \mathrm{Mg} \mathrm{ha}^{-1}$ in age of 4748 years and from 58.5 to $63.7 \mathrm{Mg} \cdot \mathrm{ha}^{-1}$ in age 58-62 years that comparable with our data for stands with close age.

Growing conditions have a direct effect on the mass of carbon in ground vegetation. In the studied Sphagnosa type pine forests on waterlogged soils, its contribution to the total carbon stocks was higher both in relative (8-11\%) and absolute (3.6-5.1 Mg.ha-1) values in comparison with Lichen and Mytillus types pine forests where this contribution were 1.4-3.2 \% and 4.2-6.5\%, respectively. The ANOVA showed that type of forest (or growing conditions) is a significant factor that determined ground vegetation input in total biomass $(p=0.017)$. Similar data on the relatively high share of understory in the total biomass of low-productive forests in Sweden are provided elsewhere (Nilsson and Wardle, 2005). Above we provided results of ground vegetation proportion in some pine stands of Myrtillus and Lichen types that comparable with our data for same forest types.

Biomass is a direct result of primary production and site productivity (Keeling and Phillips, 2007). The accumulation of ANPP and its constituent components is influenced by a number of factors, including growing conditions (forest type, soil properties), climate of the territory, and stand characteristics (species composition, age) (Song et al., 2018). Relatively high rates of ANPP were observed in more productive Myrtillus type Scots pine forests, while relatively low rates were found for Sphagnosa type ones, especially for the tree layer. In the Lichen and Myrtillus types of pine forests, we noticed a trend of decreasing net production with increasing stand age. In mature PS3, net production is more intense than in middle-aged PS2. This is probably due to a slow-down in the rate of development of low-productive communities under conditions of waterlogged soils (Chen et al., 2002).

As noted previously (Vanninen and Mäkelä, 2000), the distribution of increment by organs is determined by the priority and necessity of woody plants in the implementation of vital processes at different stages of development. For instance, a high proportion of needles/ leaves in all Scots pine forests were associated with a short life span and large litterfall of these organs, which requires their regular renewal. The growth of branches ensures mastering of inter-crown space at the conditions of competition between trees for sunlight. In Sphagnosa type stands with less basal area, we observed relatively high inputs of branch increments, except for PS2. The significant contribution of stem wood in old-age PL2 is due to the fact that the trees of the stand have different ages, varying from 56 to 370 years, whereas the wood is mainly accumulated by younger trees.

The authors of a previous study (Nilsson and Wardle, 2005) show that in low-productive communities, the contribution of ground vegetation to the total ANPP is higher compared to more productive ones. Similar results were observed in the studied low-productive pine forests of the Sphagnosa type. We think that this is due to a smaller sum of basal areas (by 1.1-2.1 times) and tree crown 
biomass (by 1.2-2.9 times) in these forests, providing more favorable lighting conditions for plants of the lower layer and leading to a relatively high biomass and ANPP value. Similar conclusions about light transmission role were reached by Ares et al. (2010) studying influence of thinning on understory diversity of coniferous forests in Oregon and Gonzales et al. (2013) that investigated contribution of ground vegetation in total ecosystem biomass of pine forests in France.

\section{Carbon inflow from plant litterfall}

Our data show that the carbon inflow from tree litterfall is slightly less or comparable with that of pine forests in Finland (Ukonmaanaho et al., 2008; Portillo-Estrada et al., 2013) and is approximately equal to that of Jack pine forests of Canada (Bhatti and Jassal, 2014). The authors of cited above articles reported that due to short lifespan needles and leaves has a dominant role in the total aboveground litterfall of boreal forests. Similar tend we observed for studied Scots pine stands on North-Eastern of European Plain. For these fractions we found low and medium inter-annual variation. For pine needles and birch leaves it was 5-23 and 8-25\% respectively. High variation of spruce needles is explained by minor part of spruce trees in pine forests.

As noted in (Bhatti and Jassal, 2014), most published works on the structure of tree litterfall provide data only on leaf litterfall, while the role of other organs (branches, cones, bark etc.) that make a significant contribution is poorly understood. In studied Scots pine forests this part varied from 28-40\% with significant input of branches. The pine bark has the lowest (10-31\%) inter-annual variation between other fractions. The litterfall of pine cones has a highest variation (15-105 \%) that explained by irregular cones forming.

The weather conditions (strong wind, mass of snow) influences on branch litterfall in boreal forests (PortilloEstrada et al., 2013; Bhatti and Jassal, 2014). It is a reason of intensive branch litterfall that we observed in winter. We suggest that in addition to weather conditions, the contribution of branches to litterfall can depend on stand density. At windy conditions, the branches of both the same tree and of neighboring trees come into contact more often, which can increase the number of broken branches. For instance, in the relatively dense stands PL1 (2,533 trees. ha $\left.{ }^{-1}\right), \operatorname{PM} 1\left(1,730\right.$ trees.ha $\left.^{-1}\right)$, and PS2 $\left(2,040\right.$ trees.ha $\left.^{-1}\right)$, the proportion of branches in tree litterfall was 25,15 , and $17 \%$, respectively. This was especially evident in winter, when the crowns experience an additional load in the form of snow. In the less dense stands PS3 (1,210 trees.ha $\left.{ }^{-1}\right)$ and PL2 (908 trees.ha- $\left.{ }^{-1}\right)$, branches accounted for 8 and $7 \%$ of the total mass of litterfall, respectively. Similar findings were provided by Lehtonen et al. (2004). According to their data, potential branch litterfall was higher in relatively dense, young stands with small stem diameters.

Besides weather conditions, an important factor may be the stand age (Liu et al., 2019), which, in addition to the total mass, determines the proportion of branches. In the studied Scots pine forests, we observed both an increase and a decrease in the mass of litterfall with the age of the stand, but there was no increase in the proportion of branches.

\section{Ratios between carbon stocks of the biomass, ANPP and litterfall}

Currently, the methods for calculating carbon stocks in the tree layer of forests (Cstand), which are also the longterm carbon pool (Schepaschenko et al., 2018), are more developed; therefore, it is necessary to make calculations based on these data. As noted above age of stand and soil conditions that determined forest type are leading factors that influenced on carbon fluxes in forest ecosystems. Relatively close values ANPP/Cstand ratios we observed for Scots pine forests of Sphagnosa type which practically didn't change with age. Comparatively small ANPP/Cstand ratio was calculated for Lichen type that was in 1.9 times lower than in Sphagnosa type and in 1.6-2.5 times than in Myrtillus type. The highest ANPP/Cstand ratio was observed for middle-aged PM1 that characterized by intensive net primary production on this stage of development. The rate of ANPP decreased on 1.6 times with stand maturing that declined ANPP/Cstand correlation in PM2 in 2.0 times. The similar tends ANPP and ANPP/Cstand ratio we observed in Scots pine stands of Lichen type however intensity was lower. This tendency is due to lower biomass and high primary production rate on the early stages of pine stands development. As presented Kolari et al. (2004) for Southern Finland carbon stocks in biomass of 75-year-old Scots pine stands is in 20.9 and 1.3 times higher than in 12-year-old and 40 -year-old pine stands respectively. However its intensity of $\mathrm{CO}_{2}$ uptake is comparable with 12-year-old stand and lowers in 1.1 times than in 40 year-old pine stands. As noted Bhatti and Jassal (2014) in site Thompson (Canada) biomass of 98 -year-old Jack pine stand is higher on $10 \%$ than 76-year-old stand but NPP rate in more young forest is slightly intensive.

The ratio Litterfall/Cstand varied widely and minimal value was less in three times than maximal. Relatively high Litterfall/Cstand ratio has pine forests of Sphagnosa type that explained by small stand biomass and comparable flux of litterfall with other studied pine stands. By contrast for Lichen types we observed comparatively low value of Litterfall/Cstand ratio due to large carbon stocks in trees and less litterfal. In pine forests Sphagnosa and Lichen types we detected decreasing this rate with stand age increasing in 1.7 and 2.4 times respectively whereas in Myrtillus type was inverse process.

Thus increasing carbon stocks in tree biomass with stand development negatively influenced both on ANPP/ Cstand and Litterfall/Cstand ratios. This data fits into the general laws of the formation of stands in boreal zone when the intensity of ANPP and litterfall declines with an age increasing (Kazimirov et al., 1977; Chen et al., 2002; Zha et al., 2013; Payne et al., 2019). On investigated ratios there is a positive influence of site conditions. The lowest mean ratios of ANPP/Cstand and Litterfall/Cstand we observed for Lichen type that developed on the poorest sandy soils with soil moisture deficit. The maximal mean value ANPP/Cstand and Litterfall/Cstand ratios were detected for Myrtillus and Sphagnosa types respectively.

In next paragraph we will discuss investigated ratios in comparably with boreal pine forests of some regions that we calculated using literature data. This sources contained 
data about carbon stocks in biomass and carbon fluxes in ANPP and litterfall for self-same sites. Our data are slightly higher than the ANPP/ Istand ratio calculated on data presented by Bhatti and Jassal (2014) for Canadian Jack pine forests, which varies from 0.013 to 0.022 , but they are comparable to Litterfall/Cstand (variation from 0.010 to 0.018 ). In the Myrtillus and Vaccinium types Scots pine forests in Karelia, the ANPP/C $C_{\text {biomass }}$ ratio varies from 0.018 to 0.062 , while the Litterfall/ $C_{\text {biomass }}$ varies from 0.018 to 0.036 (Sin'kevich et al., 2009). For Scots pine forests in Southern Sweden, the Litterfall/Cstand ratio was 0.023 (Hanson et al., 2013), while in Finland, it was 0.020 (Ukonmaanaho et al., 2008). These literature data show that the analyzed ratios vary within a fairly close range and can therefore be used for assessing carbon fluxes in large regions using remote data collection of forest biomass.

\section{CONCLUSION}

Our study provides data about carbon stocks in biomass and fluxes with ANPP and litterfall in Scots pine forests of different types in Komi Republic (North-East of European part Russia). Total carbon stocks varied from 38.5 to $75.1 \mathrm{Mg}$.ha with relatively low storages in pine forests of Sphagnosa type. We found that trees concentrate the most carbon of biomass and the main carbon pool is a stem wood that share rich into 57-62\%. We detected that ground vegetation had high both values absolute $\left(3.6-5.1 \mathrm{Mg} \cdot \mathrm{ha}^{-1}\right)$ and relative (8-11\%) in Scots pine stands on overwetted soils compared with forests of Myrtillus and Lichen types. The ANPP accounted for $2-5 \%$ of the carbon stock in the biomass. Despite the small biomass, needles and branches had a large share in ANPP what is needed for the renewal of organs with a short life span and the occupying of the surrounding space. The role of ground vegetation in the aboveground net production was significant, which is $7-29 \%$ with higher values in stands on waterlogged soils. The binding of carbon in the process of above-ground net production exceeded its losses with litterfall in 1.12-3.65 times. The highest rate of litterfall observed in maturing pine forests of Myrtillus and Lichen type. Needles and leaves formed $62-72 \%$ of annual litterfall. Using obtained data we calculated ratio between ANPP and Cstand that varied from 0.018 to 0.056 . Ratio between Litterfal and Cstand was lower and ranged from 0.008 to 0.024 . We found that all studied components of carbon cycle depend on forest types.

\section{ACKNOWLEDGEMENT}

The authors would like to thank Michail Kuznetsov and Svetlana Naimyshina from the 'Institute of biology of Komi scientific center of Ural Branch RAS' for partly helping during collecting and laboring experimental data. The article was prepared while doing research work "Spatial and temporal dynamics of structure and productivity of forest and mire ecosystems at the Northeast European Russia" number of registration AAAA-A17-117122090014-8 and partly supported by Complex Program of Ural Branch RAS (project 18-4-4-29).

\section{AUTHORSHIP CONTRIBUTION}

\author{
Project Idea: AFO \\ Funding: AFO, KSB \\ Database: AFO \\ Processing: AFO, INK, KSB \\ Analysis: AFO, INK \\ Writing: AFO
}

Review: AFO

\section{REFERENCES}

ARES, A.; NEILL, A.R.; PUETTMANN, K.J. Understory abundance, species diversity and functional attribute response to thinning in coniferous stands. Forest Ecology and Management, v. 260, p. 1104-1113, 2010.

BHATTI, J. S.; JASSAL, R. S. Long term aboveground litterfall production in boreal jack pine (Pinus banksiana) and black spruce (Picea mariana) stands along the Boreal Forest Transect Case Study in western central Canada. Ecoscience, v. 21, p. 301-314, 2014.

CHEN, W. J.; CHEN, J. M.; PRICE, D.T.; CIHLAR, J. Effects of stand age on net primary productivity of boreal black spruce forests in Ontario, Canada. Canadian Journal of Forest Research, v. 32, p. 833-842, 2002

FAO. Global forest resources assessment 2010. FAO, Rome, 2010.122p.

GONCHAROVA, I. A.; SOBACHKIN, R. S. Variations in the annual increment and net production of Hylocomium splendens in the southern taiga forests of Krasnoyarsk krai. Russian Journal of Ecology, v. 45, p. 345-350, 2014.

GONCHAROVA, O.YU; MATYSHAK, G.V.; BOBRIK, A.A.; TIMOFEEVA, M.V.; SEFILYAN A.R. Assessment of the contribution of root and microbial respiration to the total efflux of $\mathrm{CO}_{2}$ from peat soils and Podzols in the North of Western Siberia by the method ${ }^{2}$ of component integration. Eurasian Soil Science, v. 52, p. 206-217, 2019.

GONZALEZ, M.; AUGUSTO, L.; GALLET-BUDYNEK, A.; XUE, J.; YAUSCHEWRAGUENES, N.; GUYON, D.; TRICHET, P.; DELERUE, F.; NIOLLLET, S.; ÁNDREASSON, F.; ACHAT, D.L.; BAKKER, M.R. Contribution of understory species to total ecosystem aboveground and belowground biomass in temperate Pinus pinaster Ait. forests. Forest Ecology and Management,. v. 289, p. 38-47, 2013.

HANSSON, K.; FRÖBERG, M.; HELMISAARI, H.-S.; KLEJA, D. B.; OLSSON, B.A.; OLSSON, M.; PERSSON, T. Carbon and nitrogen pools and Duxes above and below ground in spruce, pine and birch stands in southern Sweden. Forest Ecology and Management, v. 309, p. 28-35, 2013.

KAZIMIROV, N. I.; VOLKOV, A. D.; ZYABCHENKO, S. S.; IVANCHIKOV, A. A.; MOROZOVA, R. M. Exchange of matter and energy in the pine forests of the European North. Leningrad: Nauka, 1977. [in Russian]. 304p.

KEELING, H. C.; PHILLIPS, O. L. The global relationship between forest productivity and biomass. Global Ecology and Biogeography, v. 16, p. 618-631, 2007.

KOLARI, P.; PUMPANEN, J.; RANNIK, Ü.; ILVESNIEMI, H.; HARI, P.; BERNINGER, F. Carbon balance of different aged Scots pine forests in Southern Finland. Global Change Biology, v. 10, p. 1106-1119, 2004.

LAIHO, R.; OJANEN, P.; ILOMETS, M.; HÁJEK, T.; TUITTILA, E.-S. MosS production in a boreal, forestry-drained peatland. Boreal Environment Research, v. 16, p. 441-449, 2011.

LEHTONEN, A : SIEVÄNEN, $R$ : MÄKELÄ A: MÄKIPÄÄ, $R$; KORHONEN, $K$. T HOKKANEN, T. Potential litterfall of Scots pine branches in southern Finland. Ecological Modelling, v. 180, p. 305-315, 2004.

LIU, X: ZHOU, T.: LUO, H. XU, P.; GAO, S.; LIU, J. Models ignoring spatial heterogeneities of forest age will signi $\square$ cantly overestimate the climate effects on litterfall in China. Science of the Total Environment, v. 661, p. 492-503, 2019.

LV, G. H.; ZHOU, G.; WANG, X. Factors controlling litterfall production of forest in China. Advanced Materials Research, v. 726, p. 4248-4251, 2013.

MATTHEWS, E. Global litter production, pools, and turnover times: Estimates 
from measurement data and regression models. Journal of Geophysical Research, v. 102, p.18771-18800, 1997.

MOKANY, K.; RAISON, R.J.; PROKUSHKIN, A. S. Critical analysis of root: shoot ratios in terrestrial biomes. Global Change Biology, v. 12, p. 84-96, 2006.

NEUMANN, M.; UKONMAANAHO, L.; JOHNSON, J.; BENHAM, S.; VESTERDAL, L.; NOVOTNY, R.; VERSTRAETEN, A.; LUNDIN, L.; THIMONIE, A MICHOPOULOS, P; HASENAUE, H. Quantifying carbon and nutrient inpu from litterfall in European forests using field observations and modeling. Global Biogeochemical Cycles, v. 32, p. 784-798, 2018

NILSSON, M.-C.; WARDLE, D. A. Understory vegetation as a forest ecosystem driver: evidence from the northern Swedish boreal forest. Frontiers in Ecology and the Environment, v. 3, p. 421-428, 2005.

ORTIZ, C.; LISKI, J.; GÄRDENÄS, A.; LEHTONEN, A.; LUNDBLAD, M.; STENDAHL, J. EGREN, G.; KARLTUN, E. Soil organic carbon stock changes in Swedish forest soils - a comparison of uncertainties and their sources through a national inventory and two simulation models. Ecological Modeling, v. 251, p. 221-231, 2013.

PAN, Y.; BIRDSEY, R. A.; FANG, J.; HOUGHTON, R.; KAUPPI, P. E.; KURZ, W A.; PHILLIPS, O. L.; SHVIDENKO, A.; LEWIS, S. L.; CANADELL, J. G.; CIAIS, P. JACKSON, R. B.; PACALA S. W.; MCGUIRE, A.; PIAO, S.; RAUTIAINEN, A SITCH, S.; HAYES, D. A large and persistent carbon sink in the world's forests. Science, v. 333, p. 988-993, 2011.

PARK, A. Carbon storage and stand conversion in a pine-dominated boreal forest landscape. Forest Ecology and Management, v. 340, p. 70-81, 2015.

PAYNE, N.J.; CAMERON, D.A., LEBLANC, J.-D., MORRISON, I.K. Carbon storage and net primary productivity in Canadian boreal mixedwood stands. Journal of Forest Research, v. 30, p. 1667-1678, 2019

PORTILLO-ESTRADA, M.; KORHONEN, J. F. J.; PIHLATIE, M.; PUMPANEN, J.; FRUMAU, A. K. F.; MORILLAS, L.; TOSENS, T.; NIINEMETS, U.' Inter- and intraannual variations in canopy fine litterfall and carbon and nitrogen inputs to the forest flor v. 70 , p. 367-379, 2013.

R Development Core Team. R: A language and environment for statistical computing. Vienna, Austria: R Foundation for Statistical Computing, 2018. Available at <http://www.R-project.org/> Accessed in: September 22th 2019

REPOLA, J. Biomass equations for Scots pine and Norway spruce in Finland. Silva Fennica, v. 43, p. 625-647, 2009

SCHAPHOFF, S.: REYER, C. P. O.; SCHEPASCHENKO, D.: GERTEN, D. SHVIDENKO, A. Tamm Review: Observed and projected climate change impacts on Russia's forests and its carbon balance. Forest Ecology and Management, v. 361, p. 432-444, 2016.

SCHEPASCHENKO, D.; MOLTCHANOVA, E.; SHVIDENKO, A.; BLYSHCHYK, V. DMITRIEV, E.; MARTYNENKO, O.; SEE, L.; KRAXNER, F. Improved estimates of biomass expansion factors for Russian forests. Forests, v. 9, p. 312, 2018.
SCHEPASCHENKO, D. G.; MUKHORTOVA, L. V.; SHVIDENKO, A. Z.; VEDROVA, E. F. The pool of organic carbon in the soils of Russia. Eurasian Soil Science, v. 46, p. 107-116, 2013.

SHVIDENKO, A.; SCHEPASCHENKO D.; NILSSON S.; BOULOUI Y. Semi-empirica models for assessing biological productivity of Northern Eurasian forests. Ecological Modeling, v. 204, p. 163-179, 2007.

SIN'KEVICH, S. M.; BAKHMET, O. N.; IVANCHIKOV, A. A. The role of soils in the regional carbon budget of pine forests in Karelia. Eurasian Soil Science, v. 42 p. 267-276, 2009.

SMITH, P.; COTRUFO, M. F.; RUMPEL, C.; PAUSTIAN, K.; KUIKMAN, P. J.; ELLIOTT, I. A. MCDOWELL, R: GRIFFITHS, R I: ASAKAWA, S: BUSTAMANTE, M: HOUSE, ।. SOBOCKÁ 」: HARPER, R: PAN, G: WEST, P C: GERBER, I S: CLARK । M.; ADHYA, T.; SCHOLES, R. J.; SCHOLES, M. C. Biogeochemical cycles and biodiversity as key drivers of ecosystem services provided by soils. Soil, v. 1, p. $665-685,2015$

SONG, X: ZENG, X.; TIAN, D. Allocation of forest net primary production varies by forest age and air temperature. Ecology and Evolution, v. 8, p. 12163-12172, 2018.

THURNER, M.; BEER, C.; SANTORO, M.; CARVALHAIS, N.; WUTZLER, T. SCHEPASCHENKO D: SHVIDENKO A: KOMPTER, E: AHRENS, B : LEVICK S. R.; SCHMULLIUS, C. Carbon stock and density of northern boreal and temperate forests. Global Ecology and Biogeography, v. 23, p. 297-310, 2014

ŤUPEK $B$ : MÄKIPÄÄ $R$ : HEIKKINEN J: PELTONIEMI $M$ : UKONMAANAHO L.; HOKKANEN, T.; NÖJD, P.; NEVALAINEN, S.; LINDGREN, M.; LEHTONEN, A Foliar turnover rates in Finland - comparing estimates from needle-cohort and litterfall-biomass methods. Boreal Environment Research, v. 20, p. 283-304, 2015.

UKONMAANAHO, L.; MERILÄ, P.; NÖJD, P.; NIEMINEN, T. M. Litterfall production and nutrient return to the forest floor in Scots pine and Norway spruce stands in Finland. Boreal Environment Research, v. 13, p. 67-91, 2008

USOLTSEV, V.A. Biological productivity of Northern Eurasia's forests: methods, database, applications. Yekaterinburg: Ural Branch of Russian Academy of Sciences, 2007. [in Russian]. 664 p.

VANNINEN, P; MÄKELÄ, A. Needle and stem wood production in Scots pine (Pinus sylvestris) trees of different age, size and competitive status. Tree Physiology, v. 20, p. 527-533, 2000

WOZIWODA, B.; PARZYCH, A.; KOPEĆ, D. Species diversity, biomass accumulation and carbon sequestration in the understorey of post-agricultural Scots pine forest. Silva Fennica, v.48(4), 23 p., 2014

ZHA, T.S.; BARR, A.G.; BERNIER, P.Y.; LAVIGNE, M.B.; TROFYMOW, J.A.; AMIRO, B.D.; ARAIN, M.A.; BHATTI, J.S.; BLACK, T.A.; MARGOLIS, H.A.; MCCAUGHEY, J.H.: XING, Z.S.: VAN REES, K.C.J: COURSOLLE, C. Gross and aboveground net primary production at Canadian forest carbon flux sites. Agricultural and Forest Meteorology, v. 175, p. 54-64, 2013 